\title{
From Caterpillar to Butterfly: Using Modern Technology within the Current Paradigm of ESL Instruction
}

John M. Murphy

Since the introduction of language laboratories within programs of second language (L2) instruction in the 1960s, an ebb and flow of interest in the use of modern technologies has been matched by shifts in L2 learning theory. Recent advances in technology once again are prompting increased attention to the role technological resources play in L2 instructional settings. When viewed from the perspective of the 1990 s, the early use of language laboratories seems an example of a technological innovation that was ahead of its time. The problems of the past were not due to the nature of the technology itself, but to decisions on how it was implemented and to the kinds of supporting instructional resources then available. Recently, a wide variety of improved audio, video, and videodisc resources, and computer programs have become available. The following discussion begins with the familiar example of a language laboratory, and goes on to provide comprehensive guidelines for incorporating modern technology generally within the current paradigm of ESL instruction. The focus is on designing a comfortable environment for learning, selecting useful resource materials, insuring accessibility to students, promoting interactive and interpersonal communication, and providing opportunities for negotiating meanings through selfdirected learning.

\section{INTRODUCTION}

This article examines the role modern technology plays in programs of ESL ${ }^{1}$ instruction. As evidenced by a number of recent publications (Dunkel, 1991; Crookall \& Oxford, 1990; Smith, 1989), the topic is timely since increased attention is being paid to the use of technological resources in second language (L2) instructional settings. One of the more familiar examples of a technological resource used for the purpose of teaching second languages is the language laboratory. Since its widespread introduction in the 1960s, an ebb and flow of interest in using language lab technology has been matched by shifts in L2 instructional theory. A reflection of this changing state of affairs is that many ESL teachers are skeptical concerning the incorporation of this and other examples of modern technology within their teaching situations. Many teachers view current instructional approaches as being incompatible with 
emerging technological resources. As Kenner (1989), Duncan (1987), Underwood (1984), and Ely (1984) indicate, there is much confusion and misunderstanding in this area. The following discussion provides guidelines for the inclusion of modern technologies within the teaching of ESL.

While addressing the example of a language laboratory, Kenner (1989) encourages ESL teachers to make creative use of this particular technological resource within the courses they teach. The principle underpinning Kenner's discussion is that innovative uses of technology offer rich possibilities for ESL learners. Just as photocopy and ditto machines, video cassette recorders, movie and overhead projectors, tape players, and record players are adopted for L2 instructional purposes, a language laboratory is one more product of modern technology that students and teachers can learn to use effectively. In fact, it is the only one of the technological resources listed above that was initially developed for the specific purpose of teaching second and foreign languages (P. Ely, personal communication, May 9th, 1990). It is not surprising, however, that some ESL teachers have become disillusioned with language labs. High expectations accompanied their introduction within L2 programs during the $1960 \mathrm{~s}$. Audiolingual methods and the use of audiovisual teaching aids were state-of-the art during this era. Bowen, Madsen \& Hilferty (1985) point out that "the language laboratory was a major breakthrough during the Audiolingual period. But the [eventual] break with this important method was so final that the ESL [language] lab has never regained its former vitality" (p. 56).

Today's ESL teachers adapt classroom techniques from a wide range of instructional approaches. Larsen-Freeman (1987), for example, describes the field of ESL instruction as having undergone a major theoretical shift from the "unity" of the 1960s to the "diversity" of the present time. During the period of the initial introduction of language laboratory technology, the development of instructional resources in the form of audio recordings and accompanying student-texts lacked a more mature theoretical base. Language laboratory equipment was being widely used well before fundamental principles from fields such as second language acquisition (Ellis, 1986), classroom centered research (Allwright \& Bailey, 1991), and Communicative Language Teaching (Savignon, 1983) were available to language teachers. This historical course of events is understandable. It is common that practitioners implement technological innovations prior to the emergence of supporting theory (Davies, 1982; Capretz, 1969). When this 
happens, it is doubtful that the new technology will be used to its full potential.

With the benefit of hindsight, we see that the initial introduction of language labs within L2 programs was a reflection of an earlier era. Today, we have access not only to better equipment, as Kenner (1989), Ely (1983) and others have pointed out, but more satisfying approaches toward L2 instruction, more interesting instructional resources (Dunkel, 1991; Otto, 1989; Hubbard, 1987), and a more varied repertoire of instructional procedures. A decade ago, Taylor presented a then state-of-the-art discussion of the role language laboratories play in the teaching of second languages and concluded that:

... even the most sophisticated and expensive language lab installation is only as good as the software played for the students [italics added]. An [inexpensive] cassette recorder, using well-conceived English teaching cassettes with an accompanying workbook may still be a more viable "language lab" than the boothed and carpeted learning centers which play tapes that no intelligent student really wants to hear.

(Taylor, 1979, p. 238)

Taylor's comments indicate that the problems of the past were due as much to decisions on how the technology was being implemented as to the nature of the instructional materials available at that time. While audio materials now being produced for ESL students may be improving (Oprandy, 1988), are classroom teachers making better informed decisions concerning how they are used? That is, do classroom teachers implement language laboratories and other technologies with anything approaching their full potential? With a few notable exceptions (e.g., Tomizawa, 1989; Deane, Troup \& Magoto, 1989 \& 1987; Lindenau, 1986), many ESL programs have suspended attempts to incorporate the use of a language laboratory as an integral component of their curricula. For innovators in the use of such facilities there is much work to be done. One continuing conceptual problem is hinted at by Krashen (1987):

Up to now, the [language] lab has been a place where students can come to exercise their output and have it corrected. A far easier and technologically simpler use for the lab is as a supplementary source of comprehensible input. Here are some possibilities: taped stories, with pictures to aid comprehension and add to the enjoyment, radio programs, commercials on 
tape, a "cheap" library, for casual pleasure reading, filled with books that the lab is not afraid of losing. And perhaps more important, a native speaker, willing to chat with whoever comes in! (p. 42)

Krashen is proposing that an effective language laboratory provide more to students than an audio console connected electronically to individual student cubicles. Krikorian \& Pettigrew (1989) find the very notion of student cubicles to be needlessly isolating and recommend that the physical surroundings of a language laboratory be designed with the ambience of a comfortable lounge in mind. They suggest that recessed lighting, large exterior windows, comfortable chairs, and conventional desk tops without partitions, or at the very least with removable partitions, become standard features in laboratory facilities. Such a setting provides opportunities for face-to-face communication as students and teachers periodically remove their headsets and interact through direct conversations. With the current advent of a number of additional technological innovations, it may be time to introduce a broader term that encompasses but is not restricted to conventional notions of the role language laboratories play in ESL instruction. Some examples of recent innovations in instructional resources include: compact and portable audio consoles; video cassette recorders (VCRs); closed-captioned TV; video minicameras; computers for wordprocessing, simulation activities, and other aspects of computer-assisted language learning (CALL); speech-processing computers to assist in the teaching of pronunciation; fast speed dubbing machines for rapidly duplicating audio tapes; small and inexpensive cassette headset players; editing machines for manipulating audio and video selections; and interactive videodisc capability that permits interfacing between computer, video and audio materials. As this listing implies, widespread use of the term "language laboratory" may be holding us back from creating a broader vision for the technological resources and related activities ESL teachers and students need to explore.

The term "Language Acquisition Resource Center" (LARC) may be a better way for characterizing the possibilities of such facilities. ${ }^{2}$ By highlighting the phrase "language acquisition" teachers are in closer touch with current descriptions of how adolescents and adults engage in the process of learning a second language. Specifying the term "resource center" makes it easier to move beyond more restrictive notions of the kinds of resources and activities that are useful in these settings. A crucial concern is to continue exploring 
the many technological innovations that are emerging in the 1990s in addition to language laboratories. Under the broader concept of LARC, a conventional audio laboratory may become one of several essential components within a more widely focused facility. Language learners would benefit from access to a wide assortment of acquisition resources. For example, a LARC facility might include areas such as: a computer room for word-processing and CALL, a well stocked and accessible reading room along the lines that Krashen recommends, and a conversation room where target language speakers and ESL speakers can socialize in either structured or unstructured settings. A studio area equipped with video camcorders might provide ESL students with opportunities to produce video presentations for course related projects. Fast speed dubbing machines could be available, enabling LARC personnel to make copies of audio materials that students would then be able to use at home. ${ }^{3}$ In this way, students who own an inexpensive portable cassette player (e.g., a Sony Walkman) would be able to work with audio recordings at their convenience and in their own choice of surroundings. Such flexibility in the use of technological resources fits in well within the broader concept that the term "LARC" implies.

In an ESL LARC facility, a conventional, audio-resource, language laboratory should be incorporated as one of several major components. An audio laboratory provides students with opportunities for working with commercially available, or instructor created, recordings that are accompanied by textbooks. Publishers regularly supplement $\mathrm{L} 2$ materials with workbooks, pictorial graphics, video and videodisc recordings, and computer software. Many audio materials currently on the market provide students with opportunities for developing communicative competence in addition to linguistic competence (Otto, 1989). Such materials present students with: (1) high quality and clear recordings on accessible topics, (2) audio material that is thematically connected and sensitive to a student's need for constructing relevant schemata, (3) a clear distinction between macro-level listening comprehension activities and those that focus upon micro-level listening subskills, (4) contextual information in the form of visual graphics, prelistening vocabulary prompts and supplementary reading passages, (5) partial outlines or other forms of supporting linguistic-visual information, (6) comprehension checks in the form of multiple choice and true/false questions, cloze passages, discussion prompts and (7) appendices with answer keys and full or partial transcriptions of the audio recordings. ${ }^{4}$ As well as providing opportunities 
for students to listen extensively in the L2 and to practise patterns of phonological accuracy, a full range of materials designed to enhance as many aspects of ESL oral and written communication as possible becomes essential to the effective implementation of a LARC facility.

In addition to developing criteria for the selection of useful audio materials, teachers need to develop criteria for the selection of appropriate computer software as well. A number of writers propose that the kinds of computer programs most useful to L2 learners are those that stimulate discussion and communicative interactions between students (Abraham \& Liou, 1991; Crookall \& Oxford, 1991; Underwood, 1984). In fact, this criteria is relevant to the analysis of any of the instructional resources mentioned in the present discussion (e.g., computer programs, audio materials, video recordings, simulation materials, textbook-activities). Computer programs that provide opportunities for groups of students to communicate interpersonally seem more in line with current theories of second language acquisition than programs with which students work in isolation. Johnson (1991) suggests that teachers search for computer programs that "bring students together to interact, to negotiate meaning, to think, and to negotiate strategies related to the social and academic tasks at hand" (p. 79). In short, computer programs that are designed to be pro-social by encouraging L2 students to interact with others are characterized as more beneficial than those designed to be worked on individually.

In the teaching of L2 writing, one application of the principles of negotiation and collaborative interaction between learners incorporates the format of a studio workshop within computer workrooms. In such settings, "teachers and students can use a large [computer display] screen to study and edit [samples of] L2 writing collectively and collaboratively" (Johnson, 1991, p. 74). This instructional format permits groups of learners to compose a single piece of prose together, to discuss, and to edit drafts of each others' work collaboratively. In addition to the use of wordprocessing software, Willis, Johnson, and Dixon (1983) "consider computer games and simulations [that promote social interaction] to be more attractive and interesting to students than any other form of computer-based instruction" (cited in Dunkel, 1991, p. 14). Underwood (1988) describes criteria and procedures for designing interactive CALL activities that combine videodisc and computer technologies. A number of writers discuss evaluation criteria for reviewing and selecting computer programs (Chapelle, 1990; Crookall, Coleman, \& Versluis, 1990; Hubbard, 1988 \& 1987; 
Curtin \& Shinall, 1987; Young, 1988; Johnson, 1985). Their criteria consistently emphasize the need for CALL resources and activities that facilitate interactions between language learners, teachers, and other target language speakers.

\section{ALTERNATIVES: CLASS LAB, OPEN LAB, AND SELF- DIRECTED LEARNING}

Although materials and resources such as the ones discussed above seem potentially useful, teachers and administrators need to consider the following programmatic issue: Should students be required to use the technological resources available to them? It might be the case that ESL students would use LARC facilities more effectively if their participation were self-motivated and voluntary. Some learners thrive within the traditional structure of a language laboratory, for example, while others encounter only boredom, impatience and frustration (Krashen, 1987; Ely, 1984; Taylor, 1979). In one investigation of students' ability to work with CALL instructional resources Chapelle and Jamieson (1986) found that certain types of L2 learners are more likely to benefit from particular materials and resources than other students. In their study, field independent L2 learners were found to be less comfortable with certain CALL activities than field dependent learners (p. 40). These researchers caution that CALL materials do not represent a uniform learning experience for all students, but that the potential benefits CALL materials offer for instruction must be weighed against the effects of specific types of lessons on L2 students with particular learning styles and affective needs.

In the traditional format commonly associated with the use of language labs, intact classes of students meet in the laboratory and everyone practises the same material at the same time. Conventionally termed the "class lab" structure, it is a format that should continue to be available for some specific purposes (e.g., beginning level courses, an intensive course in ESL pronunciation, a course in academic lecture comprehension as described by Lebauer, 1988). A second option is to have the best possible resources available and to target the facility toward students who are interested in pursuing an autonomous, self-directed style for learning the second language with less teacher supervision and intervention. When an ESL program pursues this less familiar structure, some caution is in order. One investigation of French-speaking ESL engineering students found that although language learners can succeed within an autonomous structure, students for whom enjoyment is a prime 
motivation for learning English find self-directed learning to be a more positive experience than do less motivated students (Abe, Henner-Stanchina \& Smith, 1978). It is an open question whether or not other learner variables identified in the literature, such as instrumental versus integrative motivation (Brown, 1987, pp. 114117 ) or tolerance for ambiguity (Chapelle \& Roberts, 1986) have an impact on the experiences of those who are afforded opportunities for self-directed language learning.

A third alternative that blends elements of the preceding two is to officially require that students regularly use LARC resources and materials, on a drop-in basis, for manageable periods of time (e.g., 30 minutes per week). On pedagogical grounds this structure may appear to be somewhat out-of-step with current practice since little language acquisition can be expected to take place during a mere 30 minutes per week. However, the principle underpinning this alternative is that brief positive experiences within a LARC setting will keep students coming back for more, for longer periods of time, and coming back accompanied by their friends, once they see how effective the materials and resources can be (Sadow, 1989).

Students who are seated at a cubicle while using audio materials on an individual basis are said to be working in "library mode" within an "open lab" setting.

Most language lab users receive the greatest benefit from being able to control their own study-to be able to repeat and review just those items they have trouble with and to skip over those that cause them no problems. Only the library lab [that is, working in "library mode" within an "open lab" setting] allows students this control. It also allows a great saving of time for each student by focusing attention on just those items the student is interested in studying [italics added].

(Taylor, 1979, p. 234)

Taylor's reference to "library mode" describes a setting in which language learners are working independently. Recognizing a concern for negotiation and collaboration between learners, teachers might also provide a structure in which students have opportunities to interact with others while working with audio, video, or computer materials. Such programmatic alternatives challenge ESL teachers, program directors, and LARC coordinators to become imaginative in keeping a constant supply of effective and current materials, varied activities, and clear directions available for students who will lose interest quickly if necessary guidance and support are not easily 
accessible to them. It is relatively easy for students to meet a modest program requirement of 30 minutes per week, but teachers and administrators need to devise attractive conditions and a menu of activities that will entice students to return frequently and for longer stretches of time. H. M. Taylor (personal communication, January 3rd, 1990) also encourages teachers to incorporate some reasonable amount of regular student assessment centered upon their activities in LARC settings. He points out that student motivation suffers when self-directed learners are unable to monitor their own progress. Consequently, they may become disinterested in working with LARC materials. Students can determine when they have attained comfortable mastery of specific materials if teachers provide brief review quizzes and comprehension checks on a regular basis. The publishers of many current ESL materials provide such resources as part of instructors' manuals or answer keys corresponding with student-texts. For other materials, similar resources may have to be constructed by teachers, teaching assistants, or more advanced L2 learners. ESL students depend upon feedback on their progress, especially when completing written tasks that are based upon audio recordings.

When an ESL program pursues a structure that mixes elements of required participation with some degree of learner autonomy, the successful use of a LARC facility eventually becomes dependent upon its perceived value to students. Those in charge learn to become consumer-oriented by marketing LARC according to changing conditions of supply and demand. If students do not make efficient use of the facility, then available materials, activities, and directions have to be specially adapted to better suit their needs. A basic prerequisite is that classroom teachers be familiar with the entire inventory of LARC materials. It is important for LARC personnel to conduct workshops for teachers that introduce all available resources (e.g., audio resources, computer software, supporting textbooks). In particular, teachers need opportunities to examine such resources first hand. Another central role for LARC personnel and classroom teachers is the planning and implementation of student-outreach initiatives. Those who know the LARC inventory well should be prepared to advise students on the selection of appropriate materials. LARC personnel, teachers, or teaching assistants can advise students in formal orientation sessions, in regular classroom settings, or informally when students visit the facility. As a necessary starting point, students need access to annotated bibliographies that provide descriptive information on LARC materials. For example, separate alphabetical listings can be 
arranged according to: (1) the title of the materials, (2) the targeted proficiency levels, (3) the targeted skill areas, (4) the topics presented in listening selections, (5) the features of computer software packages, and so forth. Also, ESL students should be well informed concerning: (1) the location and hours of the LARC facility, (2) features of the hardware available, (3) the software available, (4) guidelines/suggestions for making use of LARC materials, (5) the most convenient hours for making use of the facility, etc.

Another major consideration is the issue of feedback from students. Within an innovative LARC facility students need to be able to communicate their impressions of specific materials to their peers, instructors, and LARC personnel. One means of facilitating this goal is to prominently display a large file cabinet labeled "File for Student Reaction Sheets." Within the file cabinet a separate folder is placed for each textbook, audio tape, video tape, and example of computer software available in the LARC inventory. Students who have been using LARC materials can write short comments or critical reviews for other students to read (see a sample "student's reaction form" in Appendix B). The students' written comments permit a dialogue to emerge that should prove helpful to everyone involved. Another option is to survey students' impressions of LARC materials at the end of a related course of study. Both of these procedures are useful for documenting the effectiveness of LARC to university administrators and as data bases for research purposes. By periodically reviewing students' written reactions and survey responses, LARC administrators can plan to purchase additional copies of more popular materials and to drop those that are frequently described as less useful, confusing, or boring.

The preceding model is part of an instructional design for LARC currently being explored by one large ESL program. The model is underpinned by the theoretical perspectives of Knowles (1980), Kidd (1973), and Lindeman (1961) on how adults approach learning tasks in general and the perspectives of Wenden \& Rubin (1987) and Rubin \& Thompson (1982) on how adult ESL students approach the task of learning a second language in particular. These writers emphasize that adults (that is, post-secondary school learners) are capable of initiating and directing some of their own learning experiences provided they are given the necessaty guidance, information, encouragement, and support. For example, Knowles proposes that as a person matures his or her self-concept undergoes a fundamental change away from dependency and toward self- 
direction. Emerging from this tradition, Rubin \& Thompson advise L2 learners to set their own agendas for language learning while attempting to exploit as many different resources as are available to them.

It is important to remember that unless you take charge of your own learning you will probably not succeed [italics added]. You know yourself best and should, therefore, use your selfknowledge to guide your studies regardless of your teacher's methods or what the textbook tells you to do. . . . Be independent. Follow the goals you have set for yourself even if they differ from those of your teacher or textbook.

(Rubin \& Thompson, 1982, pp. 49-51)

The sources for second language learning these writers specify include the use of language laboratories and other technologies. A pivotal role teachers can serve is to assist adult learners in exploiting these and other resources more effectively.

A major objective in planning a LARC facility should be to provide structures for the language laboratory and CALL components that encourage some degree of learner autonomy in the use of $\mathrm{L} 2$ resources and materials. This objective is important even if the teachers involved prefer using these components in whole class settings. Beyond traditional uses for such facilities, attempts should be made to provide opportunities for self-directed, studentinitiated, and cooperative learning in small groups. When a wide variety of useful resources is available, when the facility is open at convenient hours, and when students have access to necessary information on how, why, and when to use LARC materials, they are being provided with necessary support for exercising a degree of autonomy in language learning. Of course, the understanding, interest, and cooperation of classroom teachers and LARC personnel is another essential element. By requiring that students use the facility for an easily manageable amount of time per week (e.g., 30 minutes), administrators can better ensure that everyone is provided with opportunities to learn to use LARC and to become familiar with the materials and options that are available.

\section{CONCLUSION}

Renewed interest in the use of facilities such as the one described in this article comes at a time when researchers, material developers, and classroom teachers have a more realistic 
appreciation for the complexity of L2 learning processes than ever before. At the same time, non-traditional opportunities for studying a second language (e.g., self-directed learning, cooperative learning, CALL) are becoming more familiar in the literature. In light of Krashen's widely discussed theoretical position that proficiency in an L2 is increased primarily through dynamic engagement with comprehensible input (Krashen, 1985), a creative design for LARC facilities can help to provide such opportunities. However, providing resources that aim to enhance learners' engagements with comprehensible input is merely a starting point. Teachers need to envision a LARC facility as a place where ESL students have opportunities for using the $\mathrm{L} 2$ in as many different ways as possible, for negotiating meanings, and for interacting with others. Resources such as a "conversation room" or a "reading room," and providing opportunities for learning word-processing and other aspects of CALL, are just as important as an innovative language laboratory. When used effectively, a LARC facility has the potential to impact significantly upon the language learning experiences of ESL students. The technology is available today. Instructional resources are getting better and more diverse all the time. A crucial challenge is to plan ways for using these resources wisely. Teachers who implement today's technology imaginatively will be encouraging those who develop L2 instructional materials in the direction of even more sophisticated advances. The caterpillar is ready to become a butterfly! It is time to replace traditional conceptions of the nature and function of a language laboratory with the wider vision of a Language Acquisition Resource Center. 


\section{NOTES}

1. For the purposes of the present discussion, use of the term "ESL" is intended to encompass the teaching of English as a second language (ESL) and English as a foreign language (EFL).

2. I wish to acknowledge the contribution of Dr. Patricia Byrd, Dr. Donald O'Connell and Mr. Peter Peterson in developing and proposing this term.

3. The impact of recent copyright decisions has to be considered when a LARC facility begins to make available to ESL students copies of commercially published audio materials. Reasonable precautions must be taken so that an institution's practices do not impinge upon the legitimate royalty privileges of publishers and authors. See Otto (1989), Reed \& Stanek (1986), or The Official Fair-Use Guidelines (1985) for guidelines on the use of commercially produced materials in LARC settings.

4. Appendix A presents some recent examples of ESL audio/textbook materials that seem particularly useful. Readers should note that this is a very small sampling. Many more are available from publishers.

Editors' Note: Additional materials are described in A. Cumming (1990), An annotated bibliography of Canadian ESL materials, TESL Canada Journal Special Issue 2.

\section{ACKNOWLEDGEMENTS}

I wish to thank Patricia Byrd, Philip Ely, Harvey M. Taylor, and several anonymous TESL Canada reviewers for having read and commented upon earlier versions of this manuscript. Any remaining shortcomings are, of course, my own.

\section{AUTHOR}

John M. Murphy prepares L2 teachers in the Department of Applied Linguistics and ESL, Georgia State University. His publications have appeared in the English for Specific Purposes (in press), TESOL Quarterly (1991), TESL Canada Journal (1989), 
Research \& Teaching in Developmental Education (1987), and the TESOL Newsletter. John's current research agenda highlights Classroom Centered Research in programs of L2 teacher education.

\section{REFERENCES}

Abe, D., Henner-Stanchina, C., \& Smith, P. (1978). New approaches to autonomy: Two experiments in self-directed learning. Mélanges Pédagogiques. Université de Nancy: C.R.A.P.E.L. (ERIC Document Reproduction Service No. ED 148 120).

Abraham, R. \& Liou, H. (1991). Interaction generated by three computer programs: Analysis of functions of spoken language. In P. Dunkel (Ed.), Computer-assisted language learning and testing: Research issues and practice. New York: Newbury House.

Allwright, D. \& Bailey, K. (1991). Focus on the language classroom: An introduction to classroom research for language teachers. New York: Cambridge University Press.

Bowen, J. D., Madsen, H., \& Hilferty, A. (1985). TESOL: Techniques and procedures. New York: Newbury House.

Brown, H. D. (1987). Principles of language learning \& teaching (2nd ed.). Englewood Cliffs, N. J.: Prentice-Hall.

Capretz, P. (1969). The language laboratory: A relic of the past or the solution to the future? NALLD Journal, 4, 32-42.

Chapelle, C. (1990). The discourse of computer-assisted langauge learning: Toward a context for descriptive research. TESOL Quarterly, 24, 199-225.

Chapelle, C. \& Jamieson, J. (1986). Computer-assisted language learning as a predictor of success in acquiring English as a second language. TESOL Quarterly, 20, 27-46.

Chapelle, C. \& Roberts, C. A. (1986). Ambiguity tolerance and field independence as predictors of proficiency in English as a second language. Language Learning, 36, 27-45.

Crookall, D., Coleman, D. W., \& Versluis, E. (1990). Computerized language learning simulation: Form and content. In D. Crookall \& R. Oxford (Eds.), Simulation, gaming, and language learning (pp. 165-182). New York: Newbury House.

Crookall, D. \& Oxford, R. (Eds.). (1990). Simulation, gaming, and language learning. New York: Newbury House. 
Curtin, C. \& Shinall, S. (1987). Teacher training for CALL and its implications. In W. F. Smith (Ed.), Modern media in foreign language education: Theory \& implementation (pp. 255-285). Lincolnwood, IL: National Textbook Co.

Davies, N. (1982). Foreign/second language education and technology in the future. NALLD Journal, 3, 5-14.

Deane, D., Troup, L., \& Magoto, J. (1987). Don't blame the technology: A checklist for planning technology-assisted lessons. The Journal of Educational Techniques and Technologies, 20, 4044.

Deane, D., Troup, L., \& Magoto, J. (1989). Video, audio, computer: A common plan of attack. Paper presented at the 1989 National TESOL Convention, San Antonio, Texas.

Duncan, J. (1987). Technology assisted teaching techniques. Brattleboro, Vermont: Pro Lingua Associates.

Dunkel, P. (1991). The effectiveness research on computer-assisted instruction and computer-assisted language learning. In $P$. Dunkel (Ed.), Computer-assisted language learning and testing: Research issues and practice. New York: Newbury House.

Ellis, R. (1986). Understanding second language acquisition. Oxford: Oxford University Press.

Ely, P. (1984). Bring the lab back to life. New York: Pergamon Press (Language Teaching Methodology Series).

Hubbard, P. (1987). Language teaching approaches, the evaluation of CALL software, and design implications. In W. F. Smith (Ed.), Modern media in foreign language education: Theory \& implementation (pp. 277-253). Lincolnwood, IL: National Textbook Co.

Hubbard, P. (1988). An integrated framework for CALL courseware evaluation. CALICO Journal, 6, 51-72.

Johnson, D. (1985). Using computers to promote the development of English as a second language: $A$ report to the Carnegie Corporation. (ERIC Document Reproduction Services No. ED 278 211)

Johnson, D. (1991). Second language and content learning with computers: Research in the role of social factors. In P. Dunkel (Ed.), Computer-assisted language learning and testing: Research issues and practice. New York: Newbury House.

Kenner, R. (1989). A defensive driving course for the language laboratory: Or, a master teacher tells how to use and manage language laboratory technology to improve the learning of languages. The Journal of Educational Techniques and Technologies, 22, 34-51. 
Kidd, R. J. (1973). How adults learn. New York: Association Press.

Knowles, M. (1980). The modern practice of adult education: From pedagogy to andragogy (2nd ed.). Chicago: Follett.

Krashen, S. D. (1985). The input hypothesis: Issues and implications. New York: Longman.

Krashen, S. D. (1987). Applications of psycholinguistic research in the classroom. In Michael H. Long \& Jack C. Richards (Eds.), Methodology in TESOL: $A$ book of readings. New York: Newbury House Publishers.

Krikorian, G. \& Pettigrew, J. (1989). Taking the language laboratory in new directions. Paper presented at the 1989 National TESOL Convention, San Antonio, Texas.

Larsen-Freeman, D. (1987). From unity to diversity: 25 years of language-teaching methodology. Forum, 25. Washington, DC: TESOL.

Lebauer, Roni S. (1988). Learn to listen; listen to learn. Englewood Cliffs, NJ: Prentice Hall.

Lindeman, E. C. (1961). The meaning of adult education. Montreal: Harvest House. (Original work published in 1926).

Lindenau, S. E. (1986). Improving electronic laboratory study in English as a second language programs: $A$ case in point. NALLD Journal, 19, 6-12.

Oprandy, R. (1988). A conceptual base for the analysis of ESOL listening materials (Doctoral dissertation, Teachers College, Columbia University, 1988). Dissertation Abstracts International, 49, 49-09A.

Otto, S. (1989). The language laboratory in the computer age. In W. F. Smith (Ed.), Modern technology in foreign language education: Applications and projects (pp. 12-41). Lincolnwood, IL: National Textbook Co.

The official fair-use guidelines. (1985). Friday Harbor, WA: Copyright Information Services.

Reed, M. H. \& Stanek, D. (1986). Library and classroom use of copyrighted videotapes and computer software. American Libraries, 17, A-D.

Rubin, J. \& Thompson, I. (1982). How to become a more successful language learner. Boston: Heinle \& Heinle.

Sadow, C. (1989). New life for the language lab. Paper presented at the 1989 National TESOL Convention, San Antonio, Texas.

Savignon, S. (1983). Communicative competence: Theory and classroom practice. Reading, MA: Addison-Wesley. 
Smith, W. F. (1989). Modern technology in foreign language education: Applications and projects. Lincolnwood, IL: National Textbook Co.

Taylor, H. M. (1979). A viable ESL/EFL language lab. TESOL Quarterly, 13: 229-239.

Tomizawa, S. (1989). A very popular language lab: Why and how? Paper presented at the 1989 National TESOL Convention, San Antonio, Texas.

Underwood, J. (1984). Linguistics, computers, and the language teacher: A communicative approach. New York: Newbury House.

Underwood, J. (1988). Language learning and "hypermedia". Association of Departments of Foreign Languages (ADFL) Bulletin, 19, 13-17.

Wenden, A., \& Rubin, J. (Eds.). (1987). Learning strategies in language learning. Englewood-Cliffs, NJ: Prentice Hall International English Language Teaching.

Willis, J., Johnson, J., \& Dixon, P. (1983). Computers, teaching, and learning: An introduction to computers in education. Beaverton, OR: Dilithium Press.

Young, R. (1988). Computer-assisted language learning conversations: Negotiating an outcome. CALICO Journal, March, 65-83.

\section{APPENDIX A}

Some recent examples of audio \& textbook materials that would be useful within an ESL LARC facility as described in this article are:

Battaglia \& Fisher. (1988). Yoshi goes to New York: Authentic discourse for listening comprehension. Englewood Cliffs, N. J.: Prentice Hall.

Bode, S., Whitley, C. \& James, G. (1981, Advanced; 1980, Intermediate). Listening in and speaking out: Recordings and activities for listening comprehension. New York: Longman.

Dunkel, P. \& Gorder, C. (1987). Start with listening: Beginning comprehension practice. New York: Newbury House.

Dunkel, P. \& Pialorsi, F. (1982). Advanced listening comprehension: Developing aural and note-taking skills. New York: Newbury House.

Finger, A. (1985). Tune in tonight: Listening to the news. New York: Newbury House. 
Handschuh, J. \& de Geigel, A. S. (1985). Improving oral communication: A pronunciation oral-communication manual. Englewood Cliffs, NJ: Prentice-Hall.

Lebauer, R. S. (1988). Learn to listen; Listen to learn: An advanced ESL/EFL lecture comprehension and note-taking textbook. Englewood Cliffs, NJ: Prentice Hall.

Lim, P. \& Smalzer, W. (1989). Noteworthy: Listening and notetaking skills. New York: Newbury House.

Mason, A. (1983). Understanding academic lectures. Englewood Cliffs, NJ: Prentice-Hall.

Numrich, C. (1988). Consider the issues: Advanced listening \& critical thinking skills. New York: Longman.

Orion, G. (1988). Pronouncing American English: Sounds, stress, and intonation. New York: Newbury House.

Osmand, A. \& McConochie, J. (1979). If you feel like singing. New York: Longman.

Richards, J., Hull, J., \& Proctor, S. (1991). Interchange: English for international communication. New York: Cambridge University Press.

Ruetten, M. (1986). Comprehending academic lectures. New York: MacMillan.

Sheeler, W. \& Markley, R. (1991). Sounds and rhythm: A pronunciation course (2nd ed.). Englewood Cliffs, N. J.: PrenticeHall.

\section{APPENDIX B}

Reaction Form for ESL LARC Materials

(Adapted from Tomizawa, 1989)

1) What is the title of the material you have been working with?

2) What chapter (or page numbers) did you work on? 
3) Was this material useful for you? (circle one number) 5

Excellent material

Average

Not useful

4) Do you recommend this material for other students? (circle one number)

5

4

3

2

1

Highly recommended

It's OK.

No, I do not

5) For what skill area is this material most useful? (circle one)

Listening comprehension Grammar Pronunciation

Speaking

Reading

Writing

Editing

Cultural Awareness

6) Do you have any suggestions for other ESL students on how to use this material effectively?

7) Write down some new words or phrases that you learned while working with this material:

8) Summarize: In just a few sentences, tell what this material was about

9) Your name (optional) 